\title{
Quando outras “cenas" entram em ação: considerações de moradores sobre transformações em periferias de São Paulo
}

\section{Adalton Marques}

\section{(2) OpenEdition \\ Journals}

Edição electrónica

URL: http://journals.openedition.org/aa/1802

DOI: 10.4000/aa.1802

ISSN: 2357-738X

Editora

Programa de Pós-Graduação em Antropologia Social (UnB)

\section{Edição impressa}

Data de publição: 1 julho 2016

Paginação: 173-201

ISSN: 0102-4302

\section{Refêrencia eletrónica}

Adalton Marques, "Quando outras "cenas" entram em ação: considerações de moradores sobre transformações em periferias de São Paulo», Anuário Antropológico [Online], v.41 n.1 | 2016, posto online no dia 07 junho 2018, consultado o 28 abril 2021. URL: http://journals.openedition.org/aa/1802 ; DOI: https://doi.org/10.4000/aa.1802

\section{(c) $)(1)(9)$}

Anuário Antropológico is licensed under a Creative Commons Atribuição-Uso Não-Comercial-Proibição de realização de Obras Derivadas 4.0 International. 


\section{Quando outras "cenas" entram em açáo: consideraçóes de moradores sobre transformaçóes em periferias de Sáo Paulo}

Adalton Marques

UFSCar

Neste artigo, reúno consideraçôes de moradores de bairros periféricos da zona sul da cidade de Sáo Paulo a respeito de suas experiências, que apontam para transformaçôes nessas regióes ao longo das décadas de 1990 e 2000. ${ }^{1} \mathrm{Na}$ primeira parte, procuro contrastar um memorial dos mortos, vitimados pela "violência urbana”, que parece ser uma baliza importante para meus interlocutores que nasceram até a metade dos anos 1980, e um memorial dos detidos, alvos preferenciais do nosso sistema penal (judiciário, polícia e prisóes), que se tornou decisivo para meus interlocutores mais jovens, nascidos a partir dos anos 1990. ${ }^{2}$ Não quero, com isso, sugerir uma sucessão histórica, mas remeter a preponderâncias relativas. $\mathrm{O}$ antes e o depois instaurados por esse contraste nunca puderam deixar de contabilizar presos e/ou assassinados coetaneamente.

$\mathrm{Na}$ segunda parte, monto duas "cenas" contrastivas que dáo sinais de como meus interlocutores viviam em seus bairros e de como o pensavam em relação a outras localidades. ${ }^{3}$ A primeira cena se passa no início dos anos 1990, enquanto a segunda encontra sua vez no final dos anos 2000. Nessas cenas, já é possível entrever uma mudança "geral" de conduta de que falam meus interlocutores, sustentada por um "maior cuidado" com "as palavras" e com o modo de dirigi-las aos outros, e, não raro, relacionada ao ideal de "paz" produzido pelo Primeiro Comando da Capital (PCC). A esse coletivo também é atribuída a responsabilidade pela redução dos homicídios nas periferias de São Paulo.

$\mathrm{Na}$ terceira parte, construo um diálogo no qual são emitidas diferentes apreciaçóes a respeito da "onda de assassinatos" que apavorava a Regiáo Metropolitana de São Paulo (bem como outras dezenas de cidades do estado) desde o final de maio de 2012, e se estenderia por todo o segundo semestre daquele ano; da polícia; da(s) causa(s) da "criminalidade violenta"; da "bandidagem"; da atuação do PCC; das condiçóes socioeconômicas locais; das estratégias de marketing de grandes empresas globais e estimativas acerca de seu poder de captura dos desejos; dos antigos "justiceiros" locais, muito atuantes até o final 
dos anos 1980; enfim, de como deveria ser a "sociedade". Na última parte, ofereço um contraste perspectivo a respeito das disposiçôes atuais do PCC e de sua relação com os moradores locais.

Os dados foram obtidos sem sistematicidade, durante outra pesquisa (Marques, 2014). Concentrei-me nas conversas estabelecidas com "moradores" de uma região específica da cidade, o que afasta a descrição de uma análise geral das periferias de Sáo Paulo. Assim, o artigo trata da experiência de moradores de um conjunto de bairros que se localiza na zona sul da capital paulista — São João Clímaco, Heliópolis, Jardim Patente e Vila Arapuá —, embora eu perceba ressonâncias entre o que eles dizem e o que dizem outros interlocutores da minha pesquisa a respeito de suas "quebradas" — Edu Chaves (zona norte de São Paulo), Cohab Teotonio Vilela (zona leste), Imbé (zona sul), Promissão (Diadema), São Pedro (São Bernardo do Campo) e Palmares (Santo André).

Procurei descrever as transformaçóes apontadas por meus interlocutores sem deixar, contudo, que se apagassem as diferenças que insistem em suas percepçóes acerca das mudanças, ou que se estabelecesse uma oposição muito dura entre essas mudanças percebidas de muitos modos e as continuidades que fazem vizinhos o futuro e o passado. Para isso, defini duas estratégias de escrita. Por um lado, decidi não recorrer a quadros analíticos sobre classes populares e periferia que cobrem o período tratado por meus interlocutores. Meu propósito não é preencher supostas lacunas deixadas pelas consideraçóes de meus interlocutores, apelando aos contextos descritos por pesquisadores, e nem mesmo o inverso. ${ }^{4}$ Esse procedimento pode redundar na presunção de que esses atores — interlocutores e pesquisadores - estáo tratando do mesmo plano de relaçóes, assim como pode desconsiderar interesses político-epistemológicos implicados em cada agenciamento de narrativas. Por outro, tentei evitar recursos metonímicos que essencializam a periferia com base na fala de atores "periféricos". 5 É verdade que meus interlocutores dizem que "ser de alguma quebrada é morar na periferia", e com frequência tomam "a periferia" como objeto de formulaçôes generalizantes ("o sentimento da periferia", "a violência na periferia", "o som da periferia"). ${ }^{6}$ Mas, nesses casos, é melhor explicitar que o efeito semiótico foi produzido pelos próprios interlocutores. Do contrário, corre-se o risco de perder de vista as disputas em torno desses signos.

O meu propósito, portanto, é evidenciar as disputas analíticas dos meus interlocutores em torno do que se passa na experiência "periférica", tentando me afastar de uma essencialização da periferia. Para essa tarefa, mobilizo cenasconceituais e personagens-conceituais. Bem longe do rigor que reclama pelo cientificismo, a estratégia deste artigo é construir ficçôes muito reais, colocando 
uma multidão de interlocutores na fala de um personagem, ou produzindo coalizóes de memórias sobre acontecimentos vividos em bairros periféricos. Quanto às cenas e personagens, é preciso dizer que procurei reproduzir o mais fielmente possível o som de falas ordinárias. Há um forte sentido político nesta decisão: 1) não aplicar ajustes gramaticais sobre o linguajar de meus interlocutores, sendo que eles mesmos mobilizam essa estratégia (chamemos assim) quando consideram necessário; 2) não subestimar a potência política que há na subversão que praticam sobre a língua portuguesa. ${ }^{7}$

\section{Do calendário dos que "subiram" ao calendário dos que "caíram"8}

Existe alli no bairro do Ypiranga uma arvore que o vulgo appellidou de arvore das lagrimas. É uma figueira centenaria, alta não tanto para fazer duas vezes o tamanho de uma casa commum, quasi sempre esgalhada e núa, com folhas mortas a balouçar nos ramos esgrouviados, como lagrimas que nunca tombam. [...] Conta a lenda que uma anciã para alli se encaminhava todas as tardes, o olhar extatico fixando o horizonte onde a estrada de Santos collêa barrenta, a espera do filho militar que a guerra arrebatára. Esse filho nunca mais voltou. Não o quizeram restituir intacto as boccas ferazes dos canhôes [...]. Ah! tão grande é o amor de mãe, quão doída e insupportavel é a saudade. [...] Hoje, a arvore, testemunha verde de todos os adeuses e de todos os soluços que a sua sombra acolheu, lá está agonisando tambem. Arvore de lagrimas, vive a chorar pela consumpção das proprias folhas que lhe abandonam a espaços os galhos tropegos (Victor, 1928).

Conta-se que o falecido Padre Benno certa vez tratou da trágica coincidência, quase profética, entre o nome da principal via de acesso do bairro, Estrada das Lágrimas, e a dor de numerosos familiares que perderam seus parentes queridos por conta da "violência" naquela região periférica de São Paulo. O pároco alemão, que havia chegado ao bairro na década de 1950, quando "quase tudo ainda era rural”, sabia perfeitamente a razão do batismo daquela Estrada: até as primeiras décadas do século XX, sua extensáo compreendia o que fora o trecho inicial do Caminho do Mar, imediatamente após o perímetro urbanizado da cidade; portanto, era onde familiares iam se despedir de seus parentes que viajariam a Santos, ao pé de uma figueira centenária, com as lágrimas que se deixa escorrer durante momentos de tristeza. 


\section{Imagem 1 - Figueira das lágrimas (1910)}

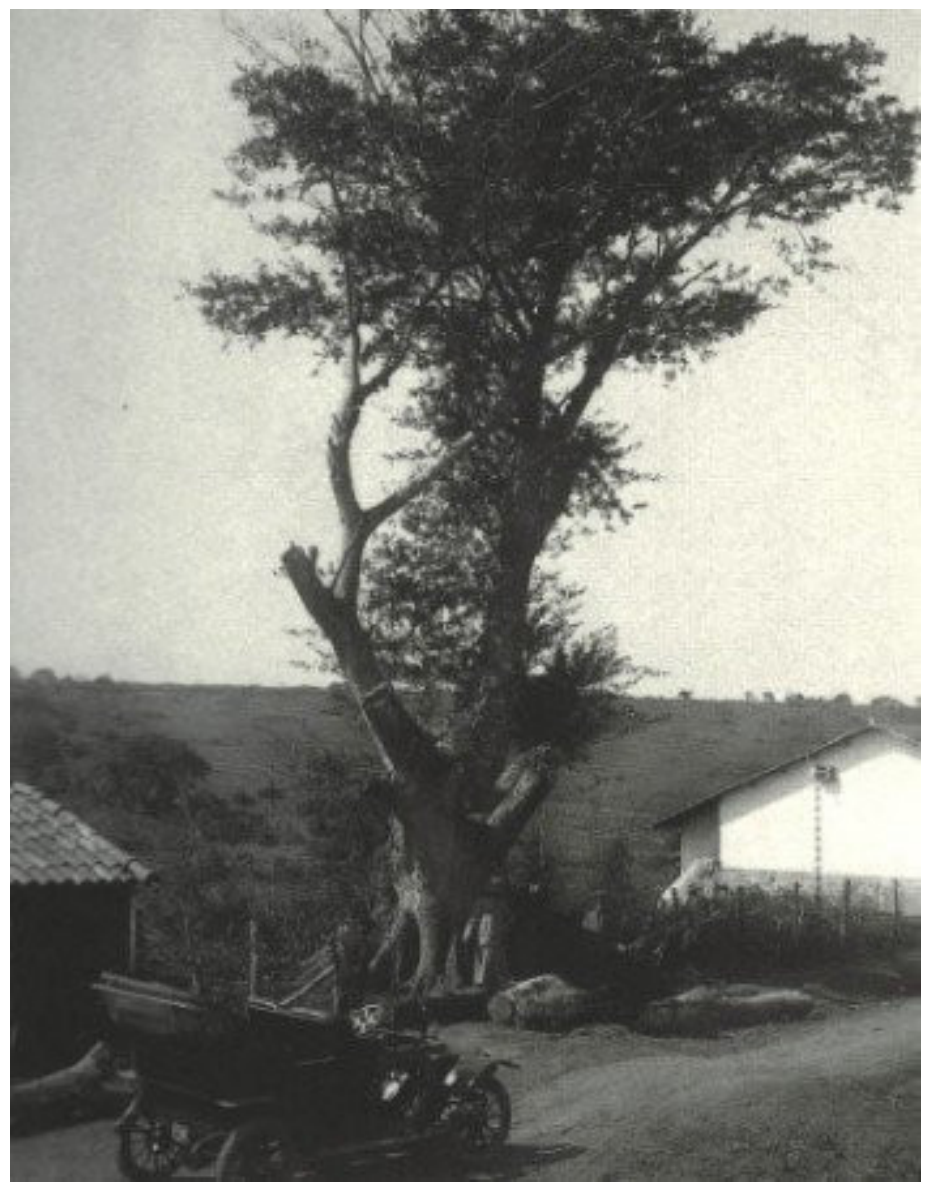

Autor não citado. Veja São Paulo, 20/05/2011

Nos dias atuais, agora com o nome do falecido padre fixado na fachada de uma das escolas da região, a EMEI Padre Benno Hubert Stollenwerk, a chamada "violência urbana" segue sua escrita marcando as ruas do bairro, derramando lágrimas de mães, pais, irmãos, filhas e amigos. Os jovens que fizeram a Primeira Comunhão até o início dos anos 1990, recebendo a benção do velho padre, tomaram as datas dos assassinatos de seus amigos como balizas para rememorar suas próprias vidas. ' Aqueles que só puderam ser batizados pelo pároco também contam seus mortos pela "violência urbana", para os quais podem rezar se a fé ainda se mantiver em pé. Mas uma contabilidade de outro tipo parece já organizar suas lembranças de modo mais completo, e sem deixar espaços temporais longos entre um acontecimento e outro. Trata-se de um memorial das prisóes de seus amigos, quando não de suas próprias passagens pela cadeia. 
Embora não seja unânime - e isso não significa a existência de contranarrativas —, há uma apreciação compartilhada entre moradores de São João Clímaco, Heliópolis, Jardim Patente e Vila Arapuá de que são esses novos sofrimentos que agora, com mais frequência, provocam as lágrimas que correm pela Estrada. É essa consistência histórica que permite a uma dona de casa dizer, alto e bom som, que outrora as mães podiam reconfortar-se ao meditar sobre o "descanso" de seus filhos assassinados ("ele sofreu muito, mas descansou nos braços do Nosso Senhor Jesus Cristo”), mas agora suas lágrimas preveem o início de longas séries de sofrimentos carcerários a que seus filhos serão submetidos ("que Nosso Senhor Jesus Cristo proteja meu filho nesse Vale da Sombra da Morte”).

Do luto aos mortos à prece aos encarcerados, um continuum de dor parece inquebrável. A reclamação contra isso, feita por ajudantes de mecânico, entregadores de pizza, pequenos comerciantes, professoras, caixas de supermercados, jovens universitários, é um autêntico gesto político. Nos versos de um rapper da região repetido em um dos muros da Estrada, som e "pixo" ainda chamam as atençóes para a trágica coincidência há muito tratada pelo falecido padre alemão: "na subida do morro, lágrimas na estrada" (Rappin Hood, 2001).

\section{Do steinhaeger com Sprite ao energético com whisky}

\section{Primeira cena}

Garoa intensa na capital paulista. São 22h48. O que vemos, ou melhor, a veloz repetição que se apresenta aos nossos olhos, é produzida pela sucessão de dezenas de esquinas escuras, dispostas ao longo da Estrada das Lágrimas. "Aqui é São João Crime”, diz a "pivetada" em referência valorativa à sua vila: São João Clímaco, bairro que, à época, se dizia pertencer ao Ipiranga. Junto a qualquer cartógrafo, ou melhor, a qualquer garoto que já aprendeu as liçóes sobre os pontos cardeais, poderíamos dizer que essa vila está localizada na regiáo sudeste da capital. Porém, a rapaziada muito louca de Steinhaeger com Sprite atualiza outra marcação territorial da cidade: "mano, nóis é zona sul! Aqui é zona sul, doidera!" Apesar de essa marcação estar de acordo com a divisão territorial oficial da Prefeitura do Município e de ter a ver com as linhas de ônibus que atravessam aquela localidade, bem como com os CEPs impressos nas contas de luz da então vigente Eletropaulo, quem anda por aquelas ruas, becos, vielas e escadóes sabe que isso tem muito mais a ver com algo que se poderia designar pela expressão sentimento de pertencimento. 


\section{Imagem 2 - Relação espacial: bairro/distrito/regiáo/zona/cidade}

\section{Territorialidade Circular da Quebrada}

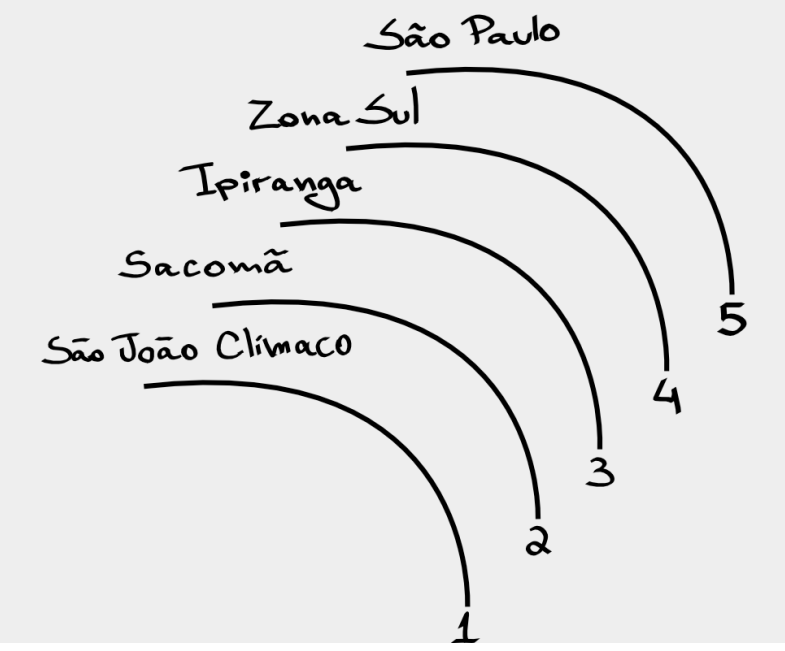

Fonte: Adalton Marques

É interessante notar que há localidades da zona sul paulistana, a região de Santo Amaro, por exemplo, que distam daquele lugar tanto quanto outros bairros da longínqua zona norte, pelo menos no que se refere à demora dos deslocamentos pelas linhas de ônibus. Por outro lado, bairros da zona leste separados dessa localidade apenas pela pequena e rica cidade de São Caetano do Sul, como a Vila Bela, a Vila Alpina e a Vila Califórnia, parecem estar a léguas de distância dali. É que estamos na fronteira entre "funçôes" ${ }^{10}$ cuja inimizade situacional está fundada em signos espaciais, muito mais do que em disposiçôes urbanas: "os cara é da zona leste, tá ligado? Nóis é sul”. A inimizade é situacional porque não tem a ver com uma divisão permanente e intransponível. Dir-se-ia que "essa treta só é levantada quando é levantada, tá ligado, mano?”. Ao que tudo indicava, havia algumas ocasióes mais propícias para tal levante: nas baladas; nos campos de futebol de várzea; nos "point's" e "rolês" de "pixadores", bem como nos "point's" e "rolês” de skatistas - - e isso atravessava a malha de ônibus e lotaçôes.

Por falar em balada, é justamente uma balada que aguardava aquela "rapaziada da zona sul", "calibrada no "goró" (bebidas alcoólicas). O destino é um "pico que rola poperô"-_ House Music americana -_ na rica, ou melhor, "playboy” São Caetano. O meio para ir: a pé, "no rolê", juntando a rapaziada de diferentes ruas e vilas em uma única "banca": descem os caras da Izonzo, 5 esquina, Categeral e São Silvestre; trombam os caras da Floresta, Lamute e uma primeira leva do Heliópolis; descendo mais tem os caras da Vila Miséria, Rua K e Barroca; com 
um breve desvio, colam os caras da Rua Any, Passagem B e a parte mais numerosa daqueles que vêm do Heliópolis; do Patente e Pombal vão poucos, mas ao final da Avenida Patente, perto da CDM (Clube Desportivo Municipal), finalmente se juntam os caras da Vila do Sapo e da Ponte Preta. Dizem que vai ter uns manos da Arapuá também "na parada": "os caras vão direto", se ouve no meio da "banca".

\section{Imagem 3 - Mapa parcial da Estrada das Lágrimas}

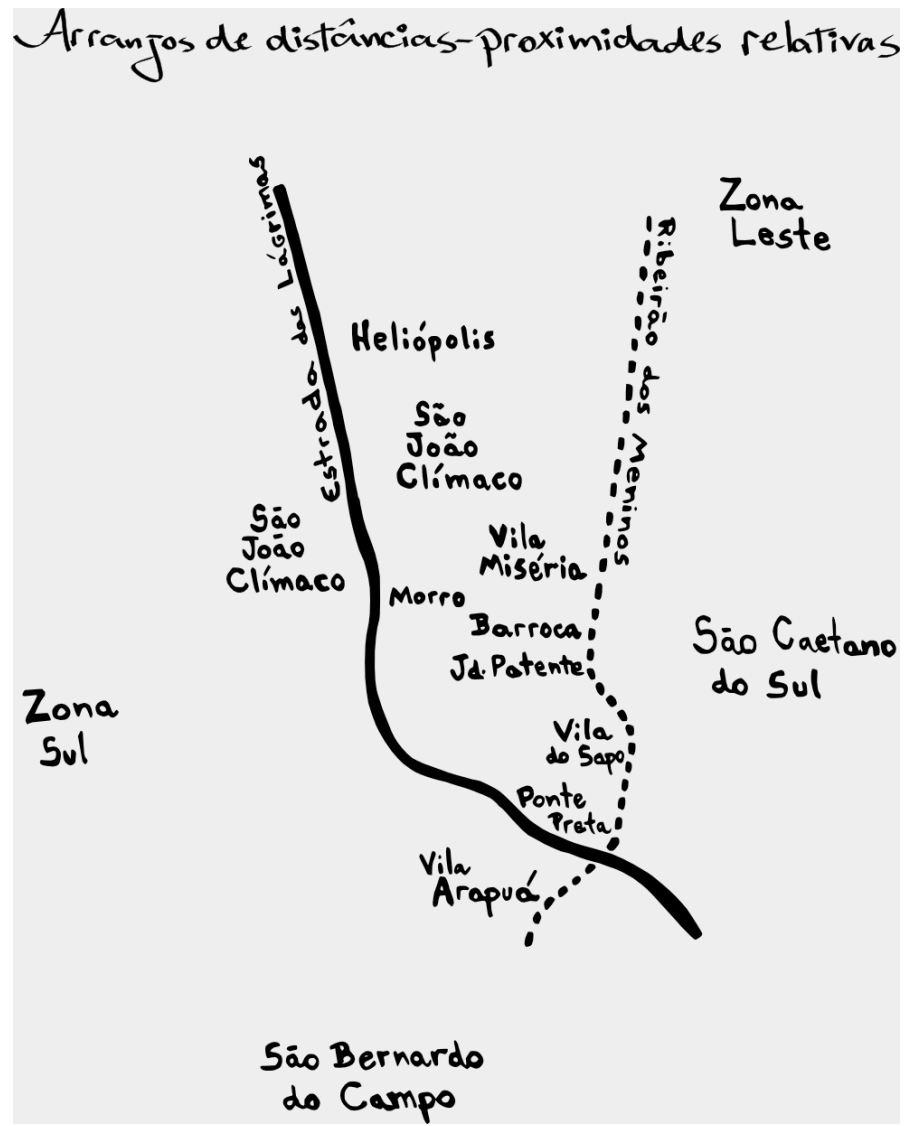

Fonte: Adalton Marques

Ao passarem a ponte, divisa entre os municípios, cantando Pânico na zona sul, do grupo de rap Racionais MC's (1990), começa-se a ouvir consideraçóes empolgantes: "a banca tá representando, tem uns 50 manos", diz um. "Só tem sangue bom", responde outro. "Só tem sangue na bobina”, enfatiza, como que corrigindo, outro garoto, que carrega na máo esquerda um copo de plástico amassado e ainda cheio de conhaque. E outras palavras desdobram a conversa, sem que seja possível, contudo, observar os rostos que as articulam: "aqui ninguém corre". 
$\mathrm{Na}$ boca de quem tomou Steinhaeger com Sprite, agora poderá se misturar o gosto de Fogo Paulista, Bombeirinho, Piper, Rabo de Galo. As combinaçôes de "goró" estão estreitamente ligadas às composiçôes e recomposiçôes de segmentos que atravessam esse ajuntamento. ${ }^{11}$ Nem todos sáo "camaradas", nem todos tomam no mesmo copo. Um deles explica: "hoje à tarde mesmo foi mó treta no campo do Copa Rio, no meio da favela. Deu mó treta. Cê tá ligado, o juizão deu mó milho [cometeu um erro imperdoável]. Aí foi foda. E o bagulho foi tenso. Tava todo mundo armado. Se não é uns correria, tinha começado a terceira guerra mundial, mano". É por isso que esse ajuntamento em movimento deve ser entendido, simultaneamente, como um segmento paralelo a outras segmentaçóes circulares mais extensivas (a rua 2; a Ponte; o Sacomã; a zona sul) e como composição e recomposição de pequenos segmentos mais ou menos duráveis. Englobamentos bem delimitados e definitivos são desafiados a todo momento pelos jogos de aliança.

Assim sendo, também seria parcial um juízo que avaliasse a qualidade ou a quantidade da maconha fumada pela rapaziada a partir da apreciação da "ponta" aproveitada aqui ("até a última ponta"), do "fino" fumado acolá ou da "bomba estourada" logo ali no meio do "bolinho"; e, ainda, da maconha "paia" trazida por fulano ou do "prensado bom pra caralho", "dixavado" por beltrano. Tem uns manos que "tão dando uns tiros" [estão usando cocaína] também, e outros que veem com maus olhos essa parada. E se no geral se diz que essa rapaziada não corre de "treta", no varejo há considerações mais específicas: "esse maluco fala pra caralho, mas não representa porra nenhuma" ou "vixi, truta, o sicrano tá de oitão. Cê tá ligado que ele senta o aço mesmo".

No caminho, algumas padarias serão roubadas, ainda que não chamem isso de roubo, é "arrastão" (com risos), e que não o vejam com seriedade, já que os produtos roubados são bebidas e sorvetes, e não o caixa. Contudo, há um trato que fora combinado sem muita cerimônia a certa altura daquele "rolê": "se a gente trombar algum playboyzinho a gente toma tudo: tênis, boné, bobojaco [jaqueta], e se marcar, até as calça”. Enfim, durante essa "camelada" até o destino almejado, outros intuitos são manifestados como projeçôes. Dizendo melhor, essa rapaziada expressa alto e bom som aquilo que "estão numas de fazer". E entre eles, pode-se "estar numas de" beber mais, ou curtir um som, ou simplesmente curtir o "rolê". Mas há dois traços constituintes fortes, grossos, inflexionando aqueles corpos em uma direção irresistível: 1) sobrepor-se às outras "bancas que vão colar na balada" e 2) "catar o máximo de mina, de preferência as boyzinhas de São Caetano que pagam um pau pros favelados" - e isso é suficiente para percebermos que máximo não se diz apenas em termos quantitativos. 
O ano é 1992; o mês, o que o leitor preferir.

\section{Segunda cena}

Noite quente nos mesmos arredores. Mais ou menos $23 \mathrm{~h} 22$. Está tudo mudado. Tem muito mais gente. Tem muito mais grana também. Claro que ainda tem muita gente na "precisão", no "veneno". "Mas porra, olha quanto carro e moto tem na quebrada", diz um astuto observador. Sabe-se bem como é mais fácil calçar um Nike agora, deixar a casa "equipadona com uma pá" de eletrodomésticos. O "centrinho" comercial de São João Clímaco agora conta com quatro bancos. Há algum tempo, um dos supermercados foi comprado e reformado por uma grande rede do ramo, enquanto o outro "não para de fechar e reabrir o tempo todo, só muda o nome”. Há algum tempo, também, se instalou por ali uma "grande farmácia", que "fica aberta todos os dias até as dez da noite". As pequenas lojas de roupa, de calçados, "1 e 99", casas de construção, lanchonetes e botecos, entre outros segmentos, aproveitam a circulação intensa e o "ímpeto de consumo da classe C" - as frases de impacto dos economistas fornecem chaves explicativas para os comerciantes locais. Não é difícil perceber que a economia local segue expandindo, na mesma intensidade em que aumenta o trânsito e se tornam raras as vagas de estacionamento nas intermediaçôes.

\section{Imagem 4 - Comércio de Sáo Joáo Clímaco}

Fonte: Adalton Marques

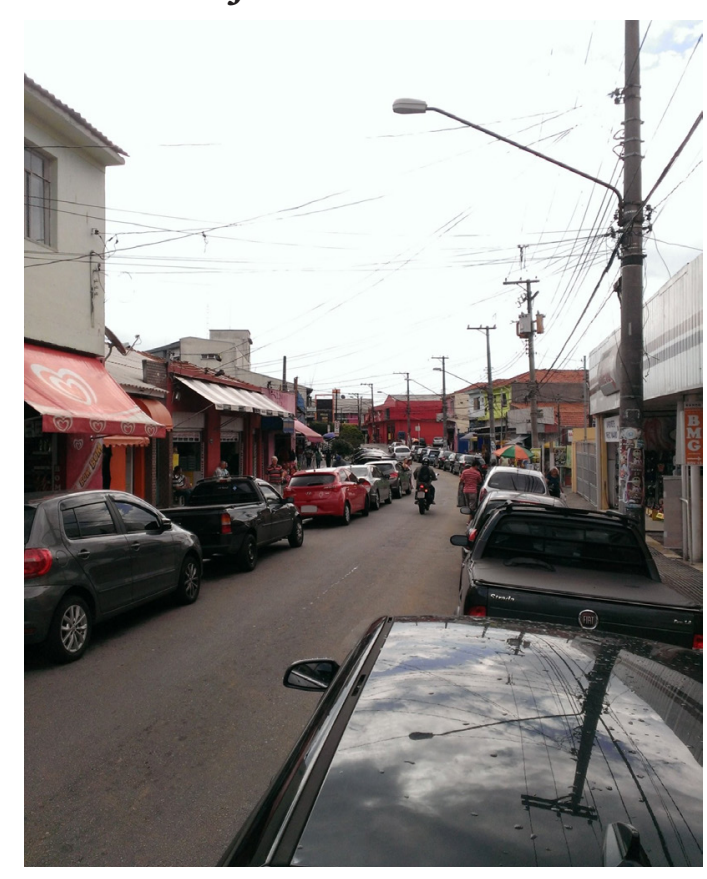


Essa expansão talvez se deva à mesma combinação de causas que intensifica a pulverizaçáo dos "centrinhos" comerciais da regiâo. Não é preciso sair do Heliópolis para conseguir tudo o que é preciso no dia a dia. A "quebrada" tem até farmácia 24 horas agora. "Abriram uma Marisa esses dias lá, guerreiro", explica um morador bastante otimista, tomando uma cerveja "de remédio", para relaxar. "E veja só", fala outro ainda, "tem um Bradesco bem em frente à favela... e não é viagem", parafraseando um trecho da música Da ponte pra cá, dos Racionais MC's (2002). Tem mais uma favela também: invadiram a Cocolândia, que era "um pico da hora pra empinar pipa, e virou mó quebrada nervosa". Do outro lado, no Heliópolis, não sobrou nenhum campo de futebol, tudo virou casa: "mas o que é mais umas casas pra uma favela de 110.000 nêgo?”, tranquiliza-nos um habilidoso jogador de várzea, que agora treina no campão da Vila Arapuá.

\section{Imagem 5 - Vista parcial de Heliópolis}

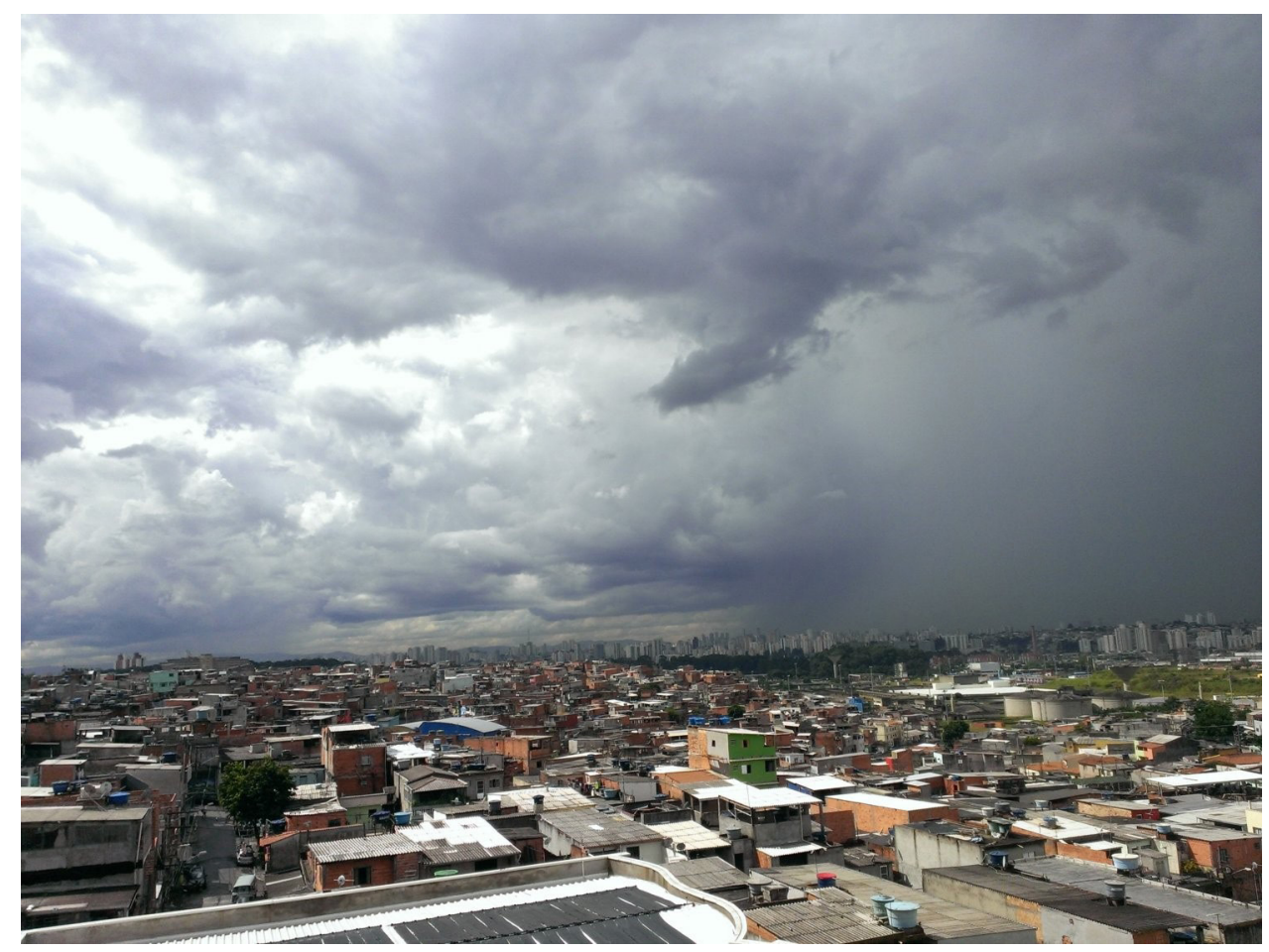

Fonte: Adalton Marques

É nessa "cena" que a rapaziada curte um funkão na rua, tomando várias garrafas de Smirnoff Ice, além de energético misturado com whisky. "Esse funk é do Catra... opa, esse que acabou de começar é do Menor do Chapa”, nos conta 
orgulhoso o dono de um dos carros dos quais emana o som da festa a alturas impressionantes. Como estão na "quebrada", está todo mundo "lado a lado". E essa sensação de "paz" é vivida em comparação ao cotidiano das "antigas", seja por conhecimento de causa, seja por narrativas dos mais velhos: "vixi, nas antigas um samba durava no máximo duas semanas. Já morria alguém e miava a fita [acabava]. Já os funks tão durando. É só chegar no sapatinho e não atrasar o lado de ninguém, nem atravessar os outros por causa de mina. Mas tá mais mamão. Falá a verdade, tá mamão com açúcar”, explica um respeitado sambista da "quebrada".

Por falar em samba, tem uma rapaziada que não vai ficar no funk. Vấo "colar" num samba lá na Cohab II, em Itaquera, no "fundáo" da Leste. Pergunta de um sujeito qualquer: "vixi, e não é embaçado, não?” Resposta: "para, guerreiro! É o mesmo ritmo daqui. Só chegar no respeito, né? Cê tá ligado que essas tretas de lado leste [zona leste] e zona show [zona sul] já foi. Essas fitas não adiantavam ninguém. Agora tá todo mundo mais no respeito".

Um pouco mais cedo, quando eu - essa espécie de observador bricoleur, déspota juntador de acontecimentos — vinha para essas paragens do Sacomá, percebi o quanto fora elaborada a chamada de atençáo que um dos passageiros direcionou ao motorista por não ter atendido ao sinal de parada, acionado com bastante antecedência. Irritaçáo coberta por um intenso treinamento: como não xingar e mesmo assim não levar desaforo para a casa? A resposta que dão a essa questáo, através daquilo que chamamos frouxamente de prática (como se se apartasse de teorizações), é também uma variação da paisagem - perceptível, notada como evidente, ainda que náo seja nominada. Atletismo de palavras... que demonstra "respeito".

Cheguei para assistir ao jogo entre dois times rivais da "quebrada". Acontecimento raro, impressionei-me com o cuidado com as palavras. Já não se ouve "vai tomar no cu" a propósito de uma entrada mais dura. Política de palavras. Política de raridade. Esses homens ensinam que aquilo que é difícil suportar deve ser encarado apenas raramente. E, durante o intervalo, espaço-tempo liberado para a "pivetada" experimentar a bola oficial e o campo reformado pela prefeitura, um garoto de 9 anos, aproximadamente, reclamou por essa raridade ao ser ofendido pelo xingamento de seu colega: "aí, guerrerinho, cê tá ligado que essas palavras não tão pelo certo. Peixe morre pela boca”.

Pelas quebradas, todos sabem que é "embaçado atrasar o lado dos outros". E fora da "quebrada"... "Vixi, fora da quebrada é tudo aliado também, é a mesma sintonia". Enfim, quanto aos "tô numas dê...", a rarefação da possibilidade de dizer "tô numas de arrumar treta" marca uma diferenciação histórica incontornável, 
para a qual os exemplos das idas aos salóes de antes e às baladas de hoje explicitam tão somente uma ponta protuberante.

Agora é 2008, não importa o mês. "Agora é outra picadilha" [outro modo de agir].

\section{Diferenças (1)}

Àquela altura, o churrasco chegava ao clímax. Assim narraria um bom roteirista em seu texto, mobilizando artifícios retóricos para fazer aparecer o ápice cósmico que conectava as poderosas batidas da roda de samba, o canto convulsivo da multidão, a rítmica coletiva expressa na dança, a embriaguez das sensaçóes, a alegria expressa em tantas faces. A verdade aérea de tal narração não é algo a ser combatido, rejeitado, negado, até que ela subjugue as diferenças. Então, quando se chega a esse ponto, é preciso dizer outras verdades. No meio daquele churrasco muitos clímax se realizavam, como forças centrífugas e/ou centrípetas a (re) organizar os corpos que ali se encontravam. Mais infinitesimalmente, milhares de encontros reconfiguravam os destinos daqueles que se encontravam sobre a laje bem-acabada, ao som da roda de samba que alegrava a noite. Misturas, comunhôes e repelências entre corpos e discursos diversos, como o líquido etílico que encontra a boca, o aparelho gástrico e o sangue de uma mulher que samba alegremente; como os beijos apaixonados e as explicitaçóes de intenções eróticas de jovens apaixonados; como os encontrôes de ombros ou os pisóes de pés que exigem as expressóes "desculpa aí", "foi mal”, "opa”, mesmo quando relaçóes amistosas sáo suficientemente fortes para evitar a menor rusga.

$\mathrm{Na}$ mureta à esquerda, no ponto exato mais distante da roda de samba, uma rápida troca de olhares conectaria pelos próximos minutos um jovem rapaz do bairro e seu cabeleireiro, homem de aproximadamente 45 anos. Não era a primeira vez que conversavam naquela festa. Contra as "zueiras" dos camaradas corintianos, que ainda se felicitavam pela recente conquista da Taça Libertadores da América, os dois já haviam reunido suas forças para retirar os méritos daquela conquista e explicitar a inferioridade numérica de títulos do time adversário. E aquela também não seria a última vez que conversariam naquela noite. As dimensóes da laje fariam com que se falassem outras tantas vezes.

Com o cuidado que é comum ver os mais velhos dispenderem sobre os mais novos, o cabeleireiro chamou-lhe a atenção a respeito do excesso de bebida ingerida naquela noite. As notícias sobre as execuçôes de "bandidos", policiais e "trabalhadores" na Região Metropolitana de São Paulo, ao longo do mês que acabara de se encerrar, mas principalmente o assassinato de um rapaz do bairro 
no dia anterior, davam sustentação à preocupação do cabeleireiro. Faziam suas palavras não serem percebidas como meras "chatices dos caras mais velhos". Atento às palavras desse seu camarada, o jovem respondeu:

— Eu tô firmão! Fica sussa [sossegado] que eu vou com a minha nêga direto pra casa. Não vou ficar vacilando por aí, não.

— É, não vacila não. Cê viu que mataram um maluco ali embaixo... insistiu o cabeleireiro, incorrendo na "chatice" ao explicitar verbalmente as circunstâncias que já eram partilhadas no diálogo.

- Ô, coroa, eu tô ligado. Cê acha que eu tô de chapéu atolado? Mas esse maluco tomou uns tiro porque era um saco de vacilo - retrucou o jovem, apontando causas para o acontecimento, como quem adiciona um traço de ordem ao caos do medo.

Com uma garrafa de cerveja cheia e pronto para encher os copos que os camaradas sustentavam em suas mãos, já quase vazios, chegava mais um parceiro na conversa, um rapper do bairro que partilhava as mesmas referências cotidianas:

- Iaí, guerreiro, qual que é a fita?

- O coroa tá em choque porque o maluco tomou uns tiro na cara lá embaixo — antecipou o jovem, respondendo ao rapper.

— Que... em choque, em choque. Cê nem sabe da fita. Isso não foi acerto de bandido, não. Tão falando aí que esse maluco subiu [foi assassinado] por causa de desacerto com os polícia. Tá cheio de polícia na área e eles estão babando pra pegar esses vagabundo que não quer saber de trabalhar. Fica vacilando na madruga pra você ver. Até você explicar que focinho de porco não é tomada, você já tomou uma salva de tiro, rapaz — retrucou o cabeleireiro, posicionando os motivos de seu temor, assim como sua aversão a "bandidos".

No mesmo passo em que dava essa resposta, o cabeleireiro viu chegar outro camarada dali, um açougueiro que fora, em outra época, um entre essas centenas de jovens que estiveram à beira de "estourar" na primeira divisão do futebol paulista. Era para ele que olhava no momento final de sua fala, como que pedindo para que apoiasse a repreensão que aplicava sobre o jovem. Pouco inclinado às consideraçôes morais que se desdobram dos acontecimentos, pôs-se a escutar as palavras que já iam saindo da boca do rapper:

— Falá a verdade, eu não sei qual que é. Só sei que tem que andar sempre ligeiro, certo? - indagação que também cobrava a fala do açougueiro.

Mas, antes que este pudesse falar, viu o jovem se adiantar no diálogo e, paciente que era, esperou mais uma vez para ter sua voz ouvida: 
- Mano, só sei que eu ando pelo certo na quebrada e não devo nada pra polícia.

- A situação tá tensa, né? Eu tava ouvindo os caras falando dessas fitas ali. O problema é que não depende só de andar pelo certo e não dever nada. O problema é alguém achar que você não está pelo certo ou que você deve alguma coisa. Às vezes você pode ser confundido, né? $\mathrm{Na}$ madrugada os caras vê neguinho gingando já joga pra cima [atira em sua direção] — ponderou o açougueiro.

—É, truta... não é só ladrão que tá morrendo, não. Tem trabalhador que tá indo pro saco, mano. Polícia é tudo racista. Se o maluco for preto e pobre, é dois palito pros cara metê bala - acrescentou o rapper, tornando a repreensão dirigida ao jovem em uma censura dirigida ao cabeleireiro.

- Vocês são engraçado! A polícia não pode errar que vocês caem de pau. Os bandido rouba e mata trabalhador e vocês não falam nada — reagiu o cabeleireiro.

- Que mata o quê, coroa! A quebrada tá mó mamão já tem uma cota [há muito tempo]. Ninguém mais mata ninguém. Só essas fitas agora que tão bagunçando a quebrada. E essas parada começaram porque aqueles verme da ROTA [Rondas Ostensivas Tobias de Aguiar, $1^{\circ}$ Batalhão de Polícia de Choque da Polícia Militar de São Paulo] mataram os caras na crocodilagem lá na Leste. Eu vi no Datena [referência ao programa Brasil Urgente, da TV Bandeirantes]. Foi aí que começou essas fita - retrucou o jovem, deslocando o objeto das apreciaçóes.

— Ô, zé ruela, eu tô falando de trabalhador, não tô falando de bandido, não. Cê tá parado no farol já vêm vagabundo meter o ferro na sua cabeça. E ai de você se deixar o carro morrer ou se os caras acharem que você é polícia - replicou o cabeleireiro, recolocando o ponto em que se detinha. Resmungando, continuou:

- Cê compra um carrinho aí em quarenta e oito vezes, trabalha noite e dia pra pagar o boleto e vagabundo vem metê o ferro... e se marcar ainda te fura inteiro.

- Não, firmeza, truta. Isso dá pra gente discutir. É uma questão social, certo? Pelo menos eu vejo as coisas assim. Mas você vem passar pano [proteger] pra polícia, mano? Porra! Os caras são tudo corrupto, vive sugando acerto [propina] de ladrão. E na ora que o bicho pega, como nessas fitas que o menino tá falando, esses caras vem e escracha a periferia — defendeu o rapper, explicitando uma crítica "social" característica de seu posicionamento.

- Que questão social, rapá! Vagabundo não quer saber de trabalhar, não. E você quer saber, a polícia tem é que matar a bandidagem toda mesmo respondeu o cabeleireiro, contrariando a posição "social" de seu camarada.

— Pera lá — interrompeu o açougueiro —, acho que vocês tão falando de coisas diferentes, mas que tấo tudo ligada no fim das contas. Você — indicando o cabeleireiro - tá inconformado com a violência da bandidagem contra os 
trabalhadores, e daí você defende o papel da polícia pra impedir isso, certo? $\mathrm{O}$ menino aqui — indicando o jovem que se desencostava da mureta - tá dizendo que na quebrada não tem mais matança igual antigamente, e que essas fitas que tấo acontecendo agora começou por causa da ROTA. ${ }^{12} \mathrm{O}$ meu parceiro aqui — batendo no ombro do rapper — tá dizendo que quando os polícia vem dá o troco por causa da execução dos seus companheiros de farda, eles não matam só bandido. Matam trabalhador também. E se o cara for negão igual nóis, fudeu.

- Caralho, coroa, não vem pagá de negão, não! Você é branco, mano exclamou o jovem para o açougueiro, em franca gargalhada, fazendo com que todos ali rissem.

- É essa fita mesmo, mano - concordou o rapper —, é uma fita de mil graus! Tem vários jeito de olhar pra essa parada, mano.

- Não é nem que tem vários jeito de olhar, é que cada um que tá nessa fita olha de jeito diferente — corrigiu o açougueiro, logo em seguida impedido de dar continuidade ao que pretendia falar.

- No meu jeito de olhar, a polícia tinha que matar a bandidagem toda. Tinha que jogar uma bomba nessas cadeia e começar tudo de novo - interrompeu o cabeleireiro.

— É? Falou! E de quem eles vão tirar a grana que eles tiram? — provocou o jovem, com riso irônico.

- Pode crê. E tem outra. Você dá essa carta branca sem pensar nas consequências, mano. Quem te garante que numa dessas os polícia não vão matar você ou eu? Preto igual eu e você não pode confiar em polícia, não - completou o rapper.

— E eu vou confiar em quem? Em bandido? Ô, não tem uma semana uns cara assaltaram o saláo que eu trabalhava antes de eu montar o meu. Eu fico fudido com essas coisa. Os cara fica em pé dez, doze hora por dia, cortando cabelo a dez reais, aí vem vagabundo e rouba tudo, até celular. Roubaram até os cliente — se irrita o cabeleireiro.

- Mano, eu concordo com você. Eu também saio de casa todo dia às seis e meia pra chegar no escritório às oito. Vou de lá direto pra faculdade, tá ligado? Ganho mó merreca. Também não acho certo os cara roubá trabalhador. Eu só não quero passá pano pra polícia — respondeu o rapper, reajustando o tom do debate.

- Eu acho que numa fita dessas aí, de os cara roubá gente humilde, né? Trabalhador, né? Tem que descer lá nos meninos e dá uma ideia neles. Os cara já passa o radinho aí e tenta vê quem foi que pegou o saláo pra devolver os bagulho - posicionou-se o jovem. 
— Cê acha que só você é espertão? Tem o menino lá, que entrou no salão tem pouco tempo, tá cortando cabelo lá tem um ano mais ou menos, ele chegou nos menino pra trocar essa ideia, pra vê se pegava pelo menos o celular dele; que é daqueles caro, tá ligado? E sabe o que os menino falou? "Porra, mano, cê tá ligado que nóis é pelo certo, né? Aqui é tudo nosso. Se fosse a rapaziada daqui a gente já fazia a busca pra te devolver. Mas foi maluco de fora. Não tem como a gente saber quem foi. E mesmo se a gente rastreasse quem foi, o cara tá na correria dele. Aí é foda" - respondeu o cabeleireiro, demonstrando conhecer o caminho das pedras apontado pelo jovem.

- Mas você vê? Os cara são humildão. É o certo pelo certo. Se tivesse no alcance deles eles já buscava o celular do menino. O Quinze é a justiça ${ }^{13}$ declamou o jovem, pretendendo que a evidência que para ele se fazia clara se estendesse aos demais.

- Que... justiça o quê? Eles são firmeza entre eles e pros conhecido deles. Cê acha que eu vou trocá ideia com bandido pra recuperar minhas coisas? Se me roubar eu vou direto na delegacia fazê um B.O. - retrucou o cabeleireiro, movimentando a cabeça em direção do açougueiro, como quem pede o estabelecimento de um laço de afirmação.

— Olha, rapaz... eu acho que vocês não tão falando a mesma língua — atendeu o açougueiro ao olhar de seus camaradas, soltando suas palavras vagarosamente. Com a cautela que lhe é característica, continuou a falar, sempre pausadamente:

— Eu acho que todos vocês táo falando a real. É que as coisas são assim complicada. Meu parceiro aqui - tocando o ombro do cabeleireiro com o olhar voltado para os demais - tá indignado com uma fita que é real. É foda você ser roubado. Outro dia um camarada meu, que joga bola comigo, foi sacar o vale dele no banco e os cara já chegou tomando. Quase que ele leva uns tiro. E foi aqui na vila. Eu fiquei indignado, porque o cara tava com o macacão da firma, macacáo sujo de graxa - concluiu parcialmente sua fala, esticando a palma da mão esquerda para o cabeleireiro, que já se apressava a complementar o fato narrado. Então, incólume à pressa alheia, continuou sua exposição pausadamente:

— Nosso truta aqui — indicando o rapper ao demais — tá trazendo uma outra fita que também é a real. Tem muita desigualdade, rapaziada. Não tem jeito. Tem muita gente querendo o que pouca gente pode até esbanjá, e no meio do caminho acaba sobrando pra aqueles que conseguem conquistar um pouquinho mais.

- Se eu quero alguma coisa eu vou trabalhar, e não roubar — esbravejou rapidamente o cabeleireiro.

- Mano, eu esperei você falar. Agora deixa eu completar o meu raciocínio protestou o açougueiro. E continuou: 
- E tem outra fita que ele colocou aqui — indicando novamente o rapper - que também é a real, mas eu não concordo com ela cem por cento. Tem que ajustar as biela! Que a polícia é corrupta e racista, ninguém aqui vai negar. Mas não é todo policial que é corrupto e racista, certo?

- Nunca ouvi falar de um que náo era - ironizou o jovem.

- Uma coisa é esses que você ouviu falar, outra é o todo da polícia. E eu tô falando isso porque eu conheço policial que é honesto. $\mathrm{O}$ cara vive com uma merreca e não faz presepada - respondeu prontamente o açougueiro. E continuou:

- Mas tem uma outra fita que você colocou aqui na mesa - indicando o jovem desta vez — que também não dá pra ser negada. Que hoje em dia, tirando essas tretas aí com a polícia, a periferia tá bem mais sossegada. E quem fez isso foi o PCC.

— Quê? Mais sossegada? Mais sossegada pra quem? Só se for pra bandidagem, que fica passando pano um pro outro. Os cara fica com essa ideinha de que tá tudo na paz, que ninguém mata ninguém. Paz é o caralho. Todo dia tem trabalhador sendo morto em assalto - protestou fortemente o cabeleireiro.

- Ah, véio, eu já escutei você falando que nas antigas o samba não durava dois final de semana e já morria um. A quebrada tá mó sossego — replicou o jovem.

— É! Daí eu pego meu poizé [carro velho], coloco ele na Bandeirantes e vem um maluco e mete o ferro na minha cabeça. Parabéns! A periferia tá em paz, mas eu que moro na periferia sou tirado de boy [pessoa rica]... se marcar ainda tomo uns tiros - advertiu o cabeleireiro.

- Eu não tô dizendo que você tá errado. Mas uma coisa é uma coisa, outra coisa é outra coisa. Essa fita que você falou aí é foda mesmo. Eu também fico indignado com trabalhador sendo assaltado. Mas o que a gente tá falando é que hoje não tem mais dessas dos caras brigar no samba e aí ficá aquela treta entre duas vilas. Cê lembra na nossa época? Cê passava em outra vila os cara já ficava encarando pra arrumar treta; cê ia nos baile, já tinha que ir preparado pra sair na mão; cê ficava com a mina da rua debaixo, os cara já ficava mordido com você. Hoje não. Hoje tem um maior respeito — ponderou o açougueiro, redirecionando o debate.

—É isso mêmo, coroa. Hoje todo mundo é aliado; tá todo mundo na mesma sintonia. Não tem mais treta na saída das escola, nas balada. Não tem mais aquelas treta dos pichador... - comemorou o jovem, interrompido pela piada do rapper:

— Ô, ô... cê nasceu na época do Pokémon, mano! Não vem pagá, não! — e continuou a sua intervenção, agora com seriedade, após se aplacarem os risos rasgados: 
— Não, é fita quente - mirando o cabeleireiro —, não tem comparação com as antigas, coroa. O PCC acabou com a matança que tinha nas periferia, colocou uma pedra numa pá de fitinha que não tinha porquê. Mano, isso aqui era uma guerra, cê tá ligado. Era um tal de fulano que ia matar o outro, o outro que ia matar o um... Isso é uma coisa. Agora outra coisa é isso que cê tá falando, das violência contra o trabalhador e tal. Então, mas daí vem essa questão da desigualdade social, mano. O governo não faz porra nenhuma. Uma pá de cara no veneno, não tem escola, não tem trampo, não tem dinheiro... - ponderou $o$ rapper, interrompido pela fala indignada do cabeleireiro:

- Cê tá de brincadeira! Nunca vi ter tanta escola, tanto trampo e tanto dinheiro na periferia. Trampo tem. Pode não ter emprego, mas trampo tem. Tem um montão de cara aí que sustenta a família puxando lixo. $\mathrm{O}$ cara não trabalha se for vagabundo. ${ }^{14}$

- As escola é tudo uma merda, guerreiro - discordou o jovem.

— Cê tem razão — concordou parcialmente o açougueiro —, mas não tem trampo pra todo mundo. Tem um monte de nêgo na precisão. E mais, se você mostra sardinha pro gato, não adianta imaginar que ele vai querer comer ração de três real o quilo!

- Mano, pra mim é essa a fita, tá ligado? O sistema joga uma pá de marca na cara dos muleque e os muleque qué os bagulho. É a porra do capitalismo. Os muleque tudo hipnotizado: Oakley, Ecko, Adidas, Nike, Lacoste. Às vezes o muleque não sabe nem o que é e sai falando "Hornet" por aí — indignado, concluiu o rapper.

- Mas os bagulho é muito louco mêmo, mano! Você também não anda de Nike? - indagou o jovem, destilando a ironia que lhe é própria.

Sem saber muito bem o que responder de bate-pronto, o rapper viu o cabeleireiro se adiantar:

- Cês acha que isso é de agora? Quando eu era muleque eu era doido pra ter um Montreal e nunca tive. Só usava Kichute. E nunca fui roubar. Por quê? Porque meu finado pai me ensinou que eu tinha que trabalhar pra conseguir as minhas coisas - protestou o cabeleireiro.

— Montreal?! Que porra é essa, coroa? — indagou o jovem, provocando gargalhadas entre os demais.

- Mas é diferente, mano veio. Não é igual antes — ressalvou o açougueiro, dissipando as risadas que ainda perduravam.

— Então a vontade de ter um bagulho antes é diferente da vontade de ter um bagulho agora? Eu morria de vergonha de ir pro baile sem um tênis legal... contava o cabeleireiro ao ser interrompido pelo rapper: 
— Ô veio cabeça dura. É o marketing, mano! Os cara descolaram um jeito de entrar na mente dos muleque.

- É, eu sou cabeça dura mesmo. Pra mim, se o cara quer alguma coisa ele tem que trabalhar pra conquistar. E bandido é bandido. Tem que ir pra cadeia. E eu náo quero saber de paz de bandido, não — assentiu o cabeleireiro a respeito de sua teimosia, reposicionando o seu modo de compreender a questão.

- Pra mim, tinha que ter menos desigualdade social e mais justiça. Daí dá pra começar a conversar - pensou alto o rapper.

— É, rapaziada, mas isso é o jeito que vocês acham que tem que ser. Só essa discussão aqui já mostra que as coisas são bem diferente — advertiu o açougueiro, saindo do silêncio no qual se colocara.

- Bão mêmo era nas antigas. Vagabundo vinha roubar pedestre, os baianão lá de baixo [referência aos antigos "justiceiros"] já sentava o ferro. Tinha até lista de quem ia cair, na padaria — relembrou o cabeleireiro. ${ }^{15}$

—É, mas os pé de pato abusavam também, né? - indagou o açougueiro, provocando o cabeleireiro.

—-E hoje, essa mulecada não abusa, não? — replicou o cabeleireiro, devolvendo a provocação ao açougueiro.

- Mas agora os cara resolve no debate. Ninguém mata antes de discutir as fitas - argumentou o rapper.

— É, parcêro, as fita passa tudo pelos irmão [referência aos componentes do PCC, também chamados de "batizados"] — complementava o jovem, ao ser interrompido pelo cabeleireiro:

- Que, passa tudo o quê? Tem uma pá de discussão de vizinho que os irmão não fica nem sabendo. Até falá que vai matar eu escuto os cara falando no meio das treta. Até macumba tem gente que faz pros outro morrer - discordou o cabeleireiro, posicionando conflitos que negariam a totalidade defendida pelos demais.

— Cê que pensa que os irmão não fica sabendo — respondeu o jovem.

— Cê acredita em macumba, veio — provocou o rapper com humor —, hein? Não. Falando sério. Pra mim, os debate não deixa as coisa descambá pras guerra que tinha antes. $\mathrm{O}$ bagulho breca a matança. $\mathrm{E}$ isso, meu velho, querendo ou não, é graças ao PCC - concluiu. ${ }^{16}$

- Ah... eu sou de outro tempo mesmo. Pra mim, tá faltando os pai falá pros filho trabalhá, dá o exemplo. Tá faltando as escola ser igual antigamente: desrespeitou, toma um safanão e vai pro castigo. E ainda apanhava quando chegava em casa. Essas menina engravida com 14 anos. Só quer saber de 
dá a buceta pra vagabundo. Daí fica tudo esses muleque sozinho. Não sabe nem quem é o pai - desabafou o cabeleireiro.

— Tá faltando justiça social, mano. Mais condição pra periferia — rebateu o rapper, dando voz novamente ao seu pensamento.

— Eu só não sei se antes era táo melhor, meu chapa — respondeu pensativo o açougueiro, indagando mais a si mesmo do que aos outros.

— Mano, eu tô ganhando daqui que a picanha ficou pronta. Dá licença aí saiu o jovem rapaz, indo em direção à churrasqueira.

Como uma força que desarranja um equilíbrio provisório, a esposa do açougueiro pediu-lhe que fossem embora, reclamando da súbita dor de cabeça que lhe acometera. O homem se despediu dos demais, dizendo que se encontrariam na quadra no dia seguinte. Como uma quase-causa, essa despedida fez com que o rapper também se colocasse em movimento, em direção à geladeira para matar a sua sede. Ali sozinho, permaneceu o cabeleireiro.

\section{Diferenças (2)}

Por volta das $6 \mathrm{~h} 50$, talvez de uma terça-feira, certamente em outubro de 2014, uma jovem que acabara de repousar no único assento do ônibus que restava vago desenhou a seguinte apreciaçáo no silêncio de seu pensamento, antes de adormecer:

preciso ter cuidado. Há muito tempo que eu não ficava sabendo de tantos assaltos cometidos contra moradores. Que absurdo! Há poucos anos, era impensável imaginar que os "correrias" [ladróes] sairiam de carro, antes das $7 \mathrm{~h}$ da manhã, roubando senhoras que aguardam no ponto de ônibus o transporte para seus trabalhos. Os próprios "irmãos" não toleravam isso. Bom, pelo menos os "irmãos" das antigas... esses de agora parecem menos comprometidos com a "quebrada". Que merda! As coisas estavam boas demais até bem pouco tempo atrás.

Se bem que eu nunca suportei "ladrão"... mas tomara que os "irmãos" das antigas saiam logo da cadeia.

Talvez um ou dois pontos adiante, onde o ônibus já se encontrava cheio, outra jovem embarcou e encostou seu corpo — peito, mãos e testa — contra o primeiro pedaço de balaústre que encontrou vazio. Antes de se entregar a cochilos intermitentes, injuriada, ela pensou nas transformaçóes que assistia em sua "quebrada": 
essa mulecada do caralho tá abusada assim, e sem responsa nenhuma, porque foi criada na paz do PCC. Como ninguém mata ninguém, e ninguém se mete na correria de ninguém, pode tudo! Pode tudo! Os caras roubam até na esquina da favela, uma rua pra cima. Porra, meu, como que o Partido [PCC] deixa isso? Será que eles não veem que isso enfraquece as ideias? Ninguém precisa fazer o papel da polícia, mas essas ideias de roubar morador tá errado! Alguém tem que fazer alguma coisa, caralho! Cadê o [fulano], cadê o [sicrano], cadê o [beltrano]? Essa quebrada tá largada...

\section{Apontamentos provisórios}

As cenas exploradas neste artigo são territórios analíticos disputados por meus interlocutores. É como analistas que eles tratam de processos de transformação que modificaram suas vidas e a experiência em seus bairros. Desse modo, se por um lado é possível dizer que o tema geral de suas consideraçóes aponta para o que se passa na experiência "periférica", por outro, é preciso dizer que é apenas na medida em que disputam os sentidos dessa experiência. Com efeito, causas da "criminalidade", atuação policial, "bandidagem", política do PCC, antigos “justiceiros”, marketing de grandes empresas globais, domínio dos próprios desejos, condiçôes socioeconômicas locais, acontecimentos locais e visóes acerca de como deveria ser a "sociedade" não são exatamente domínios inequívocos de sentidos, mas alvos oblíquos de diferentes consideraçôes. É verdade que um forte traço de concordância a respeito da inquebrantável continuidade da "violência" nas "quebradas" parece fornecer um plano estável a essas perspectivas. Mas quando nos voltamos às causas que sustentam a "violência", bem como às suas consequências, que podem exigir posicionamentos pragmáticos, novamente nos deparamos com disputas acirradas. Assim, continuidades e mudanças vão ganhando consistências relativas em cada ponto de vista. E nunca é o bastante sublinhar, quando sustentamos propósitos etnográficos, que os adjetivos parcial e fragmentário são maus qualificativos para designar os pontos de vista de qualquer interlocutor, na medida em que supóem uma totalidade acessível à análise a menos que falemos a respeito de totalidades regionais, com suas duraçóes, extensôes e capacidades de produzir efeitos.

A título de apontamentos provisórios, extraio cinco problematizaçôes das cenas descritas, com o intuito de encaminhar uma pauta de discussóes sobre as "quebradas" de São Paulo:

1. A mudança "geral" de conduta — um "maior cuidado" com "as palavras" e com o modo de dirigi-las aos outros — de que falam meus interlocutores é relacionada com bastante frequência ao ideal de "paz" produzido pelo PCC 
e à sua consequência mais conhecida nas "quebradas": a queda abrupta do número de pessoas assassinadas. Entretanto, meus interlocutores também dão indicaçôes de que a ideia de "paz" no sistema carcerário paulista é mais antiga que o PCC, embora jamais tenha conseguido a força e a formulaçáo que esse coletivo lhe deu. Também dão indicaçóes de que o hip-hop e as conversóes religiosas com destaque para as igrejas neopentecostais — intensificaram a pacificação das "quebradas". Não deixa de ser intrigante o fato de que, sob esses três agenciamentos — PCC, hip-hop e neopentecostalismo —, mobiliza-se a categoria "irmão" para se referir aos parceiros, ainda que a fraternidade do PCC responda a uma delimitação estrita, enquanto o cristianismo funda uma fraternidade universal. ${ }^{17}$ Sob essa composição de agenciamentos — e tendo diante de si pontos de vista diferentes, para não perdermos a questão etnográfica —, é problemático trabalhar com uma relação geral de causa e efeito. Ao antropólogo, não há outra forma de examinar em quais fenômenos repousam essas transformaçôes que estão em curso nas periferias de São Paulo senão perseguindo as teorizaçóes nativas.

2. O rareamento da possibilidade de levar uma "treta" [briga] às últimas consequências está intimamente relacionado à proliferação de novas alianças que recortam a cidade. As narrativas dos meus interlocutores apontam para a substituição de uma espécie de máquina (social) de produção de "tretas" por uma máquina de "fazer aliados", ou de produção de "sintonia", através da qual cada novo ponto tricotado de alianças marca um desbotamento das rixas que coloriam a cidade ("zona show" versus "lado leste" sendo apenas o paroxismo desses conflitos);

3. Essa substituição não marca o fim de "disputas", "opressóes", "violências". Antes, coloca os conflitos sob novos signos;

4. Quando dizem, avaliando negativamente a conduta de outros moradores, "se fosse nas antigas esse cara tomava um pau e se pá [talvez] até morria", interlocutores dão indicaçôes da profundidade da transformação que está em curso, na medida em que aquilo que se transforma é o plano de relaçóes que dá consistência à experiência "periférica". Portanto, transformam-se os próprios sujeitos que percorrem seus relevos, sentem suas texturas, orientam-se de acordo com a variaçáo de suas cores. Nesse sentido, a fauna de pessoas que viveram nas "vilas de periferia" (até 1990) difere profundamente da fauna de pessoas que vivem nas "quebradas" de hoje, ainda que não devamos tratar tais faunas como englobamentos das polimorfias corpóreas que as atravessam;

5. As preocupaçóes dos meus interlocutores podem nos ajudar a questionar o proveito de insistir em definiçóes meramente morfológicas ou extensivas do PCC (estrutura piramidal, não piramidal, sindical, empresarial, quantificação 
dos "batizados"), na medida em que dão indicaçôes claras de que sua política ganhou territórios mais amplos que o raio de ação de seus membros. E, talvez o mais intrigante, que essa política parece nutrir a formação de uma "conduta" que atravessa experiências não criminosas nas "quebradas".

Recebido em 20/03/2015

Aprovado em 29/03/2016

Adalton Marques é doutorando em antropologia social pela Universidade Federal de São Carlos. Realizou sua pesquisa de mestrado em antropologia social pela Universidade de São Paulo e sua graduação em sociologia e política pela Fundaçáo Escola de Sociologia e Política de São Paulo. Nessa instituição, atualmente é professor dos cursos de pós-graduaçáo (lato sensu) em "Estudos brasileiros: sociedade, educação e cultura", "Globalização e cultura" e "Psicossociologia da juventude e políticas públicas”. Também é pesquisador do Hybris — Grupo de Estudo e Pesquisa em Relaçôes de Poder, Conflitos e Socialidades (USP/UFSCar) e do Núcleo de Antropologia da Política (NuAP). Entre outras publicaçóes, é autor de Crime e proceder: um experimento antropológico (Alameda, 2014). Pesquisa prisioneiros, "comandos" prisionais, sistema penitenciário, periferia da Grande São Paulo. E-mail: adalton.marques@gmail.com 


\section{Notas}

1. Partes deste artigo foram apresentadas em comunicaçóes durante a IX Reunião de Antropologia do Mercosul (2011), a 28 ${ }^{\text {a }}$ Reunião Brasileira de Antropologia (2012) e o $36^{\circ}$ Encontro Anual da Anpocs (2012). Agradeço aos coordenadores dos grupos de trabalho, que me acolheram durante esses eventos: Neiva Vieira da Cunha (Uerj), María Carman (Conicet) e Gabriel Feltran (UFSCar); Lenin Pires (UFF) e Brígida Renoldi (UNaM); e, novamente, Neiva Vieira da Cunha e Gabriel Feltran. Também sou grato aos pareceristas que avaliaram este artigo.

2. Faço uso das aspas tanto para marcar os termos e as formulaçóes de meus interlocutores quanto para indicar a citação de autores (neste caso, seguido por referência bibliográfica). O uso de itálico fica reservado para ênfases textuais e conceituais, títulos de músicas, termos estrangeiros. Enfim, uso colchetes para esclarecer gírias locais.

3. A noção de "cena" quase nunca é mobilizada sozinha por meus interlocutores. Frequentemente, vem acompanhada de um complemento: "cena do louco" (expressão usada para qualificar açóes perigosas, mas também como hipérbole), "cena de mil grau" (descreve uma situação coberta por conflitos e tensão; também funciona como hipérbole), "cena errada" (pode funcionar como aviso ou repreensão, e mesmo como pilhéria). Mas há um uso que frequentemente é acionado após a descrição de uma circunstância, quando se diz: "essa é a cena". É a essa potência analítica de meus interlocutores que me refiro neste artigo.

4. Entendo que as explicaçóes de meus interlocutores são, elas próprias, "operaçóes de preenchimento" de lacunas, ou seja, realizam aquilo que Veyne chamou de "retrodicção" (1982:76 ss.; ver, também, Veyne, 1984:118). O propósito etnográfico, portanto, deve ser algo próximo à descrição dessas operações, e não o apelo a um contexto sociológico englobante - espécie de síntese histórica que carrega sua própria porção de preenchimentos. A propósito, é interessante o deslocamento que Goldman (2006:25) realiza sobre a noção de retrodiç̧ão de Veyne: "se a história se escreve, como quer Paul Veyne [...], por 'retrodicçáo' — ou seja, por meio do preenchimento a posteriori das lacunas de informação possibilitado por novas descobertas e por comparaçáo —, a etnografia malinowskiana seria, antes, da ordem de uma espécie de 'entredicçáo': o etnógrafo deve articular os diferentes discursos e práticas parciais (no duplo sentido da palavra, parcelares e interessadas) que observa, sem jamais atingir nenhum tipo de totalização ou síntese completa".

5. Magnani (1986) realiza uma produtiva crítica à banalização da noção de representação ao recuperar a descrição e análise de Malinowski acerca da crença dos trobriandeses nos espíritos dos mortos.

6. Em sua etnografia sobre "pixadores", Pereira também trata dessas formulaçóes generalizantes ao apontar para um movimento tanto de "particularização" quanto de "universalização" da noção de "periferia" (2010a:157). A mesma apreciação pode ser 
conferida em sua reflexão sobre a noção de risco, tomando ainda a "periferia" como locus etnográfico: "mesmo que um jovem more no bairro de Capão Redondo, na zona sul, e outro em Cidade Tiradentes, na zona leste, eles estarão, ou se sentirão, próximos, em alguns contextos, por serem ambos moradores de quebradas" (2010b:46).

7. Em outras ocasióes também decidi não corrigir os usos de linguagem de meus interlocutores (Marques, 2014:44-45; nota de rodapé $n^{\circ}$ 2) e Biondi \& Marques (2010:41-42).

8. Entre meus interlocutores é dito, comumente, que alguém "caiu" quando foi preso, e que "subiu" quando foi assassinado.

9. "O solo no qual estes indivíduos [aqueles que nasceram nas periferias da cidade no final dos anos 1970] cresceram e adentraram o mundo já foi também muito menos afeito às esperanças, até porque terrivelmente marcado pela violência (narrativas de vida de adolescentes e jovens destas regióes, hoje, necessariamente passam pela contabilidade de seus mortos) e pelo desemprego" (Feltran, 2007:107). Outros trabalhos desse pesquisador, realizados em Sapopemba, distrito periférico da zona leste de São Paulo, também tocam nessa questão, ou pelo menos tangenciam bem o problema (ver, especialmente, Feltran, 2011).

10. Em uma de suas acepçóes, "funçáo" designa uma junção de pessoas ligadas a práticas ilegais. Mas, nessa direção, corre-se sempre o risco de atualizar o faro policial e incorrer em estereótipos. Eu prefiro aproximar à noção de "função" o que é chamado, frequentemente, de "ter um conhecimento" (relativo à "quebrada"), na medida em que possibilita conexóes transversais sobre o limite entre a legalidade e a ilegalidade.

11. Barbosa (2001) toma a noção de segmentaridade como recurso analítico para pensar o tráfico de drogas no Rio de Janeiro. Goldman (2006) também mobiliza essa noção para tratar dos blocos afro de Ilhéus. Ambos realizam excelentes levantamentos da discussão antropológica sobre segmentaridade, recuperando as problematizaçôes de Fortes e Evans-Pritchard (1940) sobre alguns sistemas políticos africanos, a estruturação piramidal dessa noção na etnografia de Evans-Pritchard sobre os Nuer (1978), sua definição como teoria política nativa na etnografia de Lienhardt sobre os Dinka (1958), a multiplicação das modalidades de segmentaridade e a eliminação de sua oposição dura à formaçáo do Estado (Deleuze \& Guattari, 1996), bem como as elaboraçôes de Herzfeld (2010) a respeito da estrutura segmentar do Estado-Nação.

12. A percepção de moradores da periferia de que a atuação do PCC era responsável pela queda acentuada da taxa de homicídios no estado de Sáo Paulo, durante os anos 2000, foi levada a sério por Biondi (2007a, 2007b) quando isso parecia um tabu no debate público. Ver, também, Hirata (2010) e Feltran (2011).

13. "Quinze" e "Partido" são nomes pelos quais é conhecido o PCC. A pesquisa de Biondi (2010) é referência imprescindível para compreender a efetuação da política desse coletivo prisional. 
14. Uma crítica arguta desse "trabalho sem forma" e da trama multifacetada de ilegalismos, que já estâo no cerne do capitalismo contemporâneo, pode ser consultada nos trabalhos realizados por Telles e por Hirata, bem como na produção conjunta desses pesquisadores: "[...] o que foi considerado evidência das incompletudes da nossa modernidade náo apenas se transforma em regra (está aí para ficar), como se projetou no núcleo dinâmico de um capitalismo que fez generalizar os circuitos ilegais de uma economia globalizada nas sendas abertas pela liberalização financeira, abertura dos mercados e o encolhimento dos controles estatais" (Telles \& Hirata, 2010:40-41).

15. Os trabalhos de Telles (2011) e Hirata (2010) tratam dessa diferença histórica, chamando a atenção para a variação das organizaçôes que estão no centro da resolução de conflitos privados, comandando a gestão local da ordem e travando relaçóes diferenciais com a polícia.

16. Essa avaliação sobre os "debates" encontra uma interessante ressonância na pesquisa de Hirata sobre formas de controle social e ilegalismos populares: "considero os debates uma forma de recusa e reflexão acerca dos caminhos que conduzem à morte a partir [de] uma forma de experimentação dos critérios de respeito entre os homens" (2010:292).

17. O uso da categoria "irmão" nesses três registros foi tema de conversas rotineiras travadas com os pesquisadores Gabriel Feltran e Karina Biondi ao longo de 2011. Portanto, devo a eles a atenção que passei a dedicar a essa questão durante as conversas com meus interlocutores.

\section{Referências}

BARBOSA, Antonio Rafael. 2001. "Segmentaridade e tráfico de drogas no Rio de Janeiro". ALCEU, 2(3):166-179.

BIONDI, Karina. 2010. Junto e misturado: uma etnografia do PCC. São Paulo: Terceiro Nome.

. 2007a. "Relatos de uma rebelião: a faceta representativa do PCC". In: Anais da VII Reuniāo de Antropologia do Mercosul - Desafios Antropológicos, Porto Alegre. CDRom, v. 1.

. 2007b. "Devir-mulher: uma desterritorialização da prisão". In: Anais da XV Jornadas de Jóvenes Investigadores: investigación, integración y desarrollo. San Lorenzo (Paraguay): AUGM - Asociación de Universidades Grupo Montevideo. CD-ROM, v. 1.

BIONDI, Karina \& MARQUES, Adalton. 2010. "Memória e historicidade em dois “comandos" paulistas". Lua Nova, 79:39-70.

DELEUZE, Gilles \& GUATTARI, Félix. 1996. "1933 - Micropolítica e segmentaridade”. In: . Mil platôs: capitalismo e esquizofrenia. Rio de Janeiro: Ed. 34.v. 3, pp. 83-115. 
EVANS-PRITCHARD, E. E. 1978. Os nuer. São Paulo: Perspectiva.

FELTRAN, Gabriel. (2011). Fronteiras de tensão: política e violência nas periferias de São Paulo. São Paulo: Editora Unesp: CEM: Cebrap.

. 2007. "Vinte anos depois: a construção democrática brasileira vista da periferia de São Paulo”. Lua Nova, 72:83-114.

FORTES, Meyer \& EVANS-PRITCHARD, E. E. 1940. "Introduction". In: (eds.). African political systems. London: Oxford University Press. pp. 1-23.

GOLDMAN, Marcio. 2006. Como funciona a democracia: uma teoria etnográfica da politica. Rio de Janeiro: 7 Letras.

HERZFELD, Michael. 2010. "Segmentation and politics in the European nation-state: making sense of political events". In: Kirsten Hastrup (ed.). Other histories. New York: Routledge. pp. 62-81.

HIRATA, Daniel. 2010. Sobreviver na adversidade: entre o mercado e a vida. Tese de Doutorado, Universidade de São Paulo.

LIENHARDT, Godfrey. 1958. “The Western Dinka”. In: John Middleton \& David Tait (eds.). Tribes without rulers: studies in African segmentary systems. London: Routledge. pp. 97-135.

MAGNANI, José Guilherme Cantor. 1986. "Discurso e representação, ou de como os Baloma de Kiriwina podem reencarnar-se nas atuais pesquisas”. In: Ruth Cardoso (org.). A aventura antropológica: teoria e pesquisa. Rio de Janeiro: Paz e Terra. pp. 127-140.

MARQUES, Adalton. 2014. Crime e proceder: um experimento antropológico. São Paulo: Alameda.

PEREIRA, Alexandre Barbosa. 2010a. "As marcas da cidade: a dinâmica da pixação em São Paulo". Lua Nova, 79:143-162.

.2010b. "Os riscos da juventude". Revista Brasileira Adolescência e Conflitualidade, (3):36-50.

RACIONAIS MC's. 1990. "Pânico na zona sul". In: Holocausto urbano. São Paulo: Zimbabwe, Lado A, Faixa 1. . 2002. "Da ponte pra cá". In: . Nada como um dia após o outro dia. São Paulo: Cosa Nostra, CD 2, Faixa 10.

RAPPIN HOOD. 2001. "É tudo no meu nome". In: . Sujeito homem. São Paulo: Trama. Faixa 2, 1 CD. 
TELLES, V. S.. 2011. A cidade nas fronteiras do legal e ilegal. Belo Horizonte: ARGVMENTVM.

TELLES, Vera da Silva \& HIRATA, Daniel. 2010. "Ilegalismos e jogos de poder em São Paulo”. Tempo Social - Revista de Sociologia da USP, 22(2):39-59.

VEYNE, Paul. 1982. Como se escreve a história: Foucault revoluciona a história. Brasília: UnB.

1984. Acreditavam os gregos em seus mitos? Ensaio sobre a imaginação constituinte.

São Paulo: Brasiliense.

VICTOR, Manoel. 1928. A arvore das lagrimas. Folha da Noite, 23/06/1928. p. 3. 


\section{Resumo}

Por meio da construção de cenas, personagens, diálogos e solilóquios, reúno neste artigo consideraçôes de moradores de bairros periféricos da zona sul da cidade de São Paulo a respeito de suas experiências, que apontam para transformaçóes nessas regiōes ao longo das décadas de 1990 e 2000. Recolhidas sem sistematicidade, durante outra pesquisa, essas percepçóes tratam não apenas da redução do número de assassinatos em seus bairros, mas também da constituição de um "respeito" que acentua a aversão a xingamentos e bate-bocas, uma espécie de "cuidado" particular com "as palavras" e com o modo de dirigilas aos outros. Junto a essa mudança de "comportamento", não nominada mas notada como evidente, são tecidas consideraçôes a respeito das condiçóes socioeconômicas locais, da atuação policial, da atuaçáo do Primeiro Comando da Capital (PCC), das causas da "criminalidade violenta". Através de ficções muito reais, meu propósito é evidenciar as disputas analíticas dos meus interlocutores em torno do que se passa na experiência "periférica", tentando me afastar de uma essencialização da periferia.

\section{Palavras-chave:}

Periferias,

transformação, "violência", Primeiro Comando da Capital (PCC), ficçóes.

\section{Abstract}

Through the construction of scenes, characters, dialogues and soliloquies, I gather some perceptions of São Paulo's southern outskirts residents about their experiences indicating changes in these regions over the decades of 1990 and 2000. Collected non-systematically, during a previous research, these perceptions deal not only with the reducing number of murders in their neighborhoods, but also with the constitution of a "respect" accentuating the aversion to name-calling and to verbal squabbles. Such "respect" may be related to a kind of particular "care" with "words" and its speech performance. Along with this change of "behavior", unnamed but noted as obvious, there are some residents' perceptions about local socioeconomic conditions, police actions, actions of the First Command of the Capital (PCC) and about causes of "violent crime". Through real fictions my purpose is to highlight the analytical disputes of my interlocutors around what goes on in the "peripheral" experience, instead of essentializing the outskirts.

Keywords: Outskirts, transformation, "violence", First Command of the Capital, fictions. 